\title{
USEFULNESS OF MOBILE TEACHING AND LEARNING AS PERCEIVED BY ROMANIAN AND LITHUANIAN SCIENCE TEACHERS
}

\author{
Gabriel Gorghiu \\ Valahia University Târgoviște, Romania \\ E-mail: ggorghiu@gmail.com
}

Costin Pribeanu

Academy of Romanian Scientists, Romania

E-mail: costin.pribeanu@gmail.com

Vincentas Lamanauskas, Violeta Slekiene

Šiauliai University, Lithuania

E-mail: vincentas.lamanauskas@su.It, violeta.slekiene@su.It

\begin{abstract}
With the explosion of mobile technologies, mobile teaching and learning became an important educational challenge. Since both teachers and students are increasingly using mobile devices in their everyday life, the question is why so little progress has been made in this direction. Clearly, the initiative of introducing mobile technology in class should come from teachers. Existing research shows a large diversity of factors that are influencing their perception as regards the usefulness and opportunity of mobile teaching and learning. This research aims to understand the extent to which the expectancy of increased students' motivation and better understanding are influencing the perception of mobile teaching usefulness. A structural model has been developed and tested on two samples of science education teachers, one from Romania and the other from Lithuania. The results show that the expectancy of a better understanding of lessons by students has an important effect on the teachers 'perception of mobile teaching and learning. Keywords: educational usefulness, learning motivation, mobile teaching, mobile learning, pilot research
\end{abstract}

\section{Introduction}

With the explosion of mobile technologies, mobile teaching and learning became an important educational challenge (Ciampa, 2013; Hung, \& Zhang, 2012; Lin et al., 2016). This challenge has been augmented by the proliferation of social networking websites that are easily accessed on a mobile device. Both teachers and students are increasingly using mobile devices in their everyday life for a variety of purposes: communication, socialization, exchange of information, entertainment, content creation, and content sharing. On the other hand, mobile technology offered the possibility to design innovative methods in education.

In the actual school, and especially among children - starting here with what is happening in primary and lower secondary education - mobile technology stays in the center of their discussions mostly due to the video games. In many cases, young students exploit their networking skills, by playing online, using their mobile devices, being also incredible how much 
Gabriel GORGHIU, Costin PRIBEANU, Vincentas LAMANAUSKAS, Violeta SLEKIENE. Usefulness of mobile teaching and learning as perceived by Romanian and Lithuanian science teachers

PROBLEMS

OF EDUCATION IN THE $21^{\text {st }}$ CENTURY Vol. 78 , No. 5, 2020

720

they talk about their difficulties in overcoming a level s example or give each other advice, or help each other when scheduling meetings to resume the game. In this respect - even the mobile technology is restricted or forbidden to be exploited in many schools, or is considered as risky for young students (Thomas \& Muñoz, 2016; Walker, 2013) - they prove an important level of knowledge related to the user of their mobile devices, at their ages. As a result, it was natural for educational games to become a key-element to be introduced in the learning process in actual education. In this sense, a new concept called "gamification of education" has been born, as an approach suitable for "increasing the learners' motivation and engagement by incorporating game design elements in educational environments" (Dichev, \& Dicheva, 2017).

But step by step, young students discover the advantages of using mobile technology not only for recreation. Texting, exploring the web, retrieving information, interacting and communicating with colleagues via their mobile devices networking and collaborating, represent as many ways that allow them to mediate the process of learning, especially in informal and non-formal environments (Rideout et al., 2010). Practically, the technical devices and virtual environments are used more responsibly for scholarly purposes, and less for entertainment.

In this respect, it is clear that educational interventions must focus mainly on age categories, with important specificities from early education to high school. On the other hand, since the mobile devices became part of the everyday life of many students and teachers, the question that is said by many researchers is: why mobile teaching and learning is not so widespread, especially in formal education? In a big acceptance, the initiative of introducing mobile technology in the classroom should come from teachers. The existed research shows a large diversity of factors that influence the perception as regards the perceived usefulness and opportunity of the mobile teaching and learning (Fereira et al., 2015; Fua, \& Hwang, 2018; Lamanauskas et al., 2019; Pribeanu et al., 2020).

This research aimed to understand the extent to which the expectancy of increased students' motivation and better understanding are influencing the perception of mobile teaching usefulness. Based on preliminary research, a structural model has been developed and specified that relates four latent variables: facilitating conditions, learning motivation expectancy, better understanding expectancy, and usefulness for teaching. The model has been tested on two samples of science education teachers, one from Romania and the other from Lithuania.

\section{Background and Conceptualization}

\section{Background}

In general, it is stated that mobile technology has an impact on various usability factors such as effectiveness, efficiency, satisfaction, learnability, memorability, errors, and the cognitive load (Harrison et al., 2013). In education, the introduction of mobile technology has influenced the teaching/learning process in a positive manner. As Gray et al. (2004) pointed out, the presence of new technologies in students' and teachers' everyday life, makes the teachers develop IT skills, convey them to students and provide them with new knowledge and skills. Also, mobile technology started to rethink several methodical patterns in education, with added-value issues in problem-solving, cooperative learning, game-based learning, and technology-assisted instruction (Klopfer, et al., 2012; Lan et al., 2007; Roschelle et al., 2010; Warschauer, 2007).

When used, mobile learning seems to produce an important and visible difference in how students learn, having a positive students' perception concerning collaborative learning and valuable potential on students' knowledge and comprehension (Heflin et al., 2017). It is clear that students who use mobile devices have more confidence and greater acceptance in social groups. It is the main force for going further, with several benefits for educational purposes: 
carrying out projects, facilitating the socialization process, and improving communication IN THE $21^{\text {st }}$ CENTURY between people from any part of the world and in any language, continuously and permanently. Therefore, effective collaboration between groups may fully exploit the facilities offered by discussion forums, blogs, social websites, or even virtual worlds.

Several research studies showed that mobile technology has a positive influence on students who lack motivation because mobile devices were especially useful for creating teacher and students' relationships, which in turn facilitated the learners' involvement in the education process (Ison et al., 2004; Walsh et al., 2011).

But the usefulness for the teaching and learning process - particularly informal learning - is relevant when mobile devices are properly integrated as instruments in the didactic demarches, being combined with traditional tools, with the view to obtain an improved school experience. As most of the actual students are familiarized with digital language and known as early users of smart devices, the teachers have extensive opportunities for using such devices to facilitate the students' acquisition of competences, but also the good retention of various contents, as required by the school curricula. Unfortunately, the teachers still need more training in technological/digital skills, in order to build their instruments and resources, with the view to answer to students' needs and to increase the students' motivation for developing autonomy and analytical skills for learning (Nganji, 2018).

In theory, the nowadays school environments and their internal conditions can ensure a successful transition to another level, where blended-learning must be seen as a usual procedure, being completed with learning environments in the format of open and flexible platforms, and becoming more effective than traditional face to face learning approach (Acelajado, 2011; Saritepeci \& Cakir, 2015). By communicating seamlessly with mobile devices and cooperation tools, the content management software allows students and teachers to participate and benefit from a more dynamic learning experience, based mainly on interactive discussions.

Mobile applications are oriented on student-centered learning, accelerating, and deepening understanding and acquisition, while teachers have the opportunity to continuously assess the degree of students' knowledge. Teachers themselves noticed the increase of students' motivation and achievements when mobile learning technology has been introduced and exploited into their didactic strategies (Navaridas et al., 2013; Sung \& Mayer, 2013).

\section{Research Model and Hypotheses}

It was hypothesized that the usefulness for teaching (UT) is influenced by three factors: the facilitating conditions (FC), motivation to learn expectancy (ML), and better understanding expectancy (UU). Also, the motivation to learn expectancy (ML) is influenced by a better understanding of expectancy (UU). The proposed research model is presented in Figure 1.

\section{Figure 1}

Research model

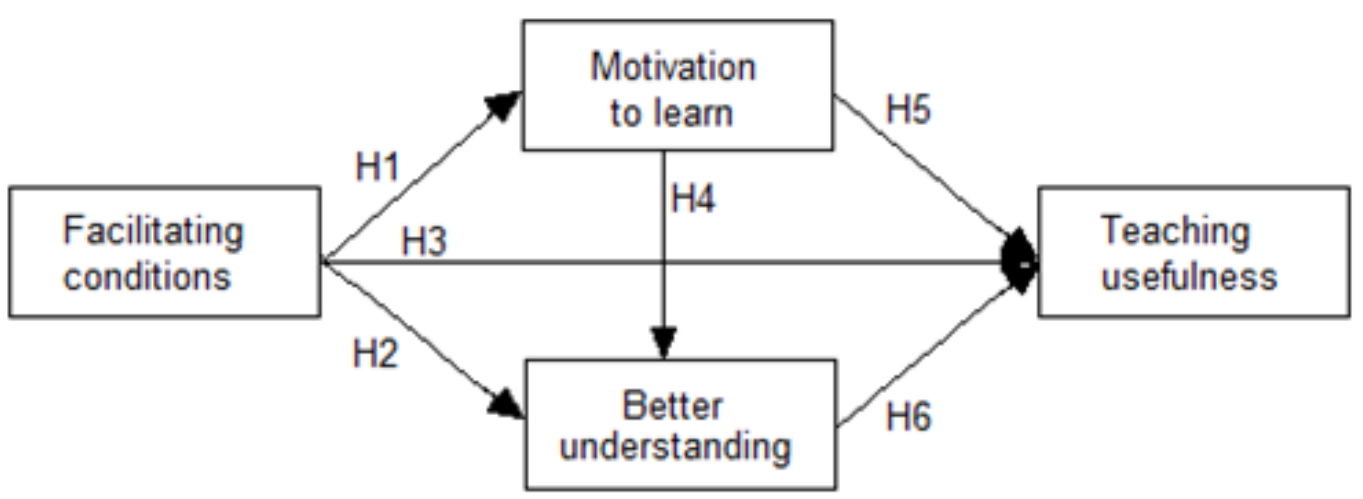


Gabriel GORGHIU, Costin PRIBEANU, Vincentas LAMANAUSKAS, Violeta SLEKIENE. Usefulness of mobile teaching and learning as perceived by Romanian and Lithuanian science teachers

PROBLEMS

OF EDUCATION IN THE $21^{\text {st }}$ CENTURY Vol. 78, No. 5,2020

The motivation to learn expectancy (ML) is measuring the increased motivation of students as anticipated by teachers. It is expected that by introducing mobile technology in class students will be less stressed and bored. It is also expected that the lessons will be perceived as more interesting and attractive (Lamanauskas et al., 2019; Ott et al., 2018).

Usefulness for teaching (UT) is measuring the new opportunities created by mobile technology (Isson et al., 2004). Teachers will be able to prepare more interesting lessons and to find ways to better explain difficult concepts (Lamanauskas et al., 2019). Moreover, teachers may find it easier to give learning tasks to students. A better understanding of expectancy (UU) is measuring the anticipated benefits as regards the understanding of concepts (Fua \& Hwangb, 2018; Lamanauskas et al., 2020).

The facilitating conditions (FC) refers to the skills needed to use mobile technology in the process of teaching and learning. These skills are a precondition for the effective implementation of mobile technology in schools (Nganji, 2018; Pribeanu et al., 2020).

$H_{1}$ Facilitating conditions has a positive influence on the motivation to learn $(F C \rightarrow M L)$

$\mathrm{H}_{2}$ Facilitating conditions has a positive influence on better understanding $(F C \rightarrow U U)$

$\mathrm{H}_{3}$ Facilitating conditions as a positive influence on the usefulness for teaching ( $F C \rightarrow$ UT)

Motivation has a positive effect on learning outcomes (Lamanauskas et al., 2019; Murayama et al., 2013; Pintrich, 2003). By using educational applications on their own devices, students will pay more attention and, consequently, will be able to better understand the lesson and creatively use their knowledge.

Teaching and learning are closely related processes. It is expected that the motivation to learn expectancy and the better understanding expectancy has a positive influence on the usefulness of teaching. In general, motivation to learn is strongly related to competence which is acquired through experience, being stimulated by modeling, communication of expectations, but also through direct instruction or socialization (Brophy, 1998). In this way, the teaching process has the main role in building an optimal relationship between teacher and student, which can enhance classroom learning and motivation (Birch \& Ladd, 1997). On the other hand, in this digital age, for raising students' better understanding of the concepts taught at school, there is a need for introducing modern technical appliances - including mobile devices - in classrooms and exploited positively, in a new format of instruction, mediated by teachers. In this respect, teachers themselves must be familiarized with the features provided by mobile devices, through particular applications dedicated to m-learning (García-Martínez et al., 2019).

$H_{4}$ Motivation to learn has a positive influence on better understanding (ML $\rightarrow U U$ )

$H_{5}$ Motivation to learn has a positive influence on usefulness for teaching (ML $\left.\rightarrow U T\right)$

$H_{6}$ Better understanding has a positive influence on usefulness for teaching (UU $\rightarrow U T$ )

The constructs and measures are presented in Table 1. 
Gabriel GORGHIU, Costin PRIBEANU, Vincentas LAMANAUSKAS, Violeta SLEKIENE. Usefulness of mobile teaching and learning as perceived by Romanian and Lithuanian science teachers

Table 1

Measures

\begin{tabular}{ll}
\hline FC & Facilitating conditions \\
\hline FC1 & Students have the skills needed to use mobile technology for learning purposes \\
\hline FC2 & I have the skills needed to use mobile technology for teaching purposes \\
\hline FC3 & I am able to find educational applications for teaching purposes \\
\hline ML & Learning motivation expectancy \\
\hline ML1 & By using mobile technology students may be less bored by the traditional methods \\
\hline ML2 & By using mobile technology students may feel in control to learn with their own devices \\
\hline ML3 & By using mobile technology students may find the lesson more attractive \\
\hline ML4 & By using mobile technology students are less stressed and learning is accepted as a game \\
\hline ML5 & By using mobile technology students may find the lesson more interesting \\
\hline UU & Better understanding expectancy \\
\hline UU1 & Mobile technology may stimulate students to pay more attention to lessons \\
\hline UU2 & Mobile learning stimulates creativity \\
\hline UU3 & Mobile technology may help to better understand the lesson \\
\hline UT & Usefulness for teaching \\
\hline UT1 & With mobile technology, I could prepare more interesting lessons \\
\hline UT2 & Mobile technology helps to give learning tasks to students \\
\hline UT3 & With mobile technology, I could better explain difficult concepts \\
\hline UT4 & With mobile technology, I could better stimulate the students to learn \\
\hline
\end{tabular}

\section{Research Methodology}

\section{Method}

The evaluation instrument has been developed based on previous preliminary research (Lamanauskas et al., 2019; Pribeanu et al., 2020). Data has been collected in two countries Lithuania and Romania. Natural science and adjacent subject teachers participated in the research (125 - from Romania, 120 - from Lithuania). The participants have been asked to answer several general questions as regards demographics, qualification, and involvement then to evaluate the items on a 5-points Likert interval scale.

An exploratory factor analysis carried on the first sample revealed poor factor loadings and cross-loading, so five items have been eliminated: FC1, ML2, UU1, UT5, and UT6.

Convergent validity has been assessed according to the recommended thresholds from the literature (Fornell, \& Larcker, 1981; Hair et al., 2010), as regards loadings magnitude (greater than 0.5 ), construct reliability (composite reliability, CR greater than 0.70 ), and average variance extracted (AVE, greater than 0.5 ). Discriminant validity has been assessed through the squared correlation test (Fornell \& Larcker, 1981).

The model fit with the data has been assessed by using the following goodness of fit indices (Hair et al., 2006; Schermelleh-Engel et al., 2003): chi-square $\left(\chi^{2}\right)$, degrees of freedom (df), $\chi^{2} / \mathrm{df}$, comparative fit index (CFI), the goodness of fit index (GFI), root mean square error of approximation (RMSEA), and standardized root mean square residual (SRMR).

The model was analyzed with Lisrel 9.3 for Windows (Mels, 2006), using a covariance matrix as input and maximum likelihood estimation method. 
Gabriel GORGHIU, Costin PRIBEANU, Vincentas LAMANAUSKAS, Violeta SLEKIENE. Usefulness of mobile teaching and learning as perceived by Romanian and Lithuanian science teachers

PROBLEMS

OF EDUCATION

IN THE $21^{\text {st }}$ CENTURY

Vol. 78, No. 5, 2020
Samples

Romanian sample

The sample of 125 teachers ( 34 men and 91 women) has a distribution by age as follows: 15 teachers in 20-29 years group, 27 teachers in 30-39 years group, 29 teachers in 40-49 years group, 43 teachers in 50-59 years age group, and 11 teachers over 60 years old.

As regards the certification, 81 teachers have the level 1 certification $(64.8 \%), 22$ teachers have the level 2 certification $(17.6 \%)$, and 22 teachers have a full-time professional degree $(17.6 \%) .70$ teachers are working with lower secondary students $\left(5^{\text {th }}-8^{\text {th }}\right.$ forms $)$ and 55 are involved in upper secondary education $\left(9^{\text {th }}-12^{\text {th }}\right.$ forms $)$.

\section{Lithuanian sample}

The distribution by age of teachers $(19(16 \%)$ male, $101(84 \%)$ female) is as follows: 3 in 20-29 years group, 14 in the 30-39 years group, 29 in the 40-49 years group, 50 in the 50-59 years group, and 24 teachers over 60 years old. As regards the qualification: 18 (15\%) were teachers, $32(26.7 \%)$ - senior teachers, 56 (46.6\%) - teachers- methodologists and $14(11.7 \%)$ teachers experts. 37 teachers work with all age group students, 21 teachers are working mainly in lower secondary education, and 62 teachers are working mainly in upper secondary education.

\section{Research Results}

\section{Model Testing Results: Romanian Sample}

The model has been analyzed for unidimensionality, the internal consistency of the scale (Cronbach's alpha), and convergent validity. The descriptive statistics and item loadings are presented in Table 2. 
Gabriel GORGHIU, Costin PRIBEANU, Vincentas LAMANAUSKAS, Violeta SLEKIENE. Usefulness of mobile teaching and learning as perceived by Romanian and Lithuanian science teachers

Table 2

Descriptive and item loadings $(N=125)$

\begin{tabular}{lllll}
\hline Factor & Item & Mean & SD & Loading \\
\hline \multirow{2}{*}{ FC } & FC1 & 4.18 & 0.87 & .69 \\
\cline { 2 - 5 } & FC2 & 4.24 & 0.81 & .92 \\
\hline & ML1 & 4.05 & 1.02 & .59 \\
\cline { 2 - 5 } & ML3 & 4.25 & 0.88 & .78 \\
\cline { 2 - 5 } & ML4 & 4.02 & 0.97 & .77 \\
\cline { 2 - 5 } & ML5 & 4.34 & 0.86 & .87 \\
\hline UU & UU2 & 3.84 & 0.95 & .70 \\
\cline { 2 - 5 } & UU3 & 4.08 & 0.79 & .90 \\
\hline UT & UT1 & 4.26 & 0.80 & .81 \\
\cline { 2 - 5 } & UT2 & 4.06 & 0.79 & .77 \\
\cline { 2 - 5 } & UT3 & 4.08 & 0.82 & .89 \\
\cline { 2 - 5 } & UT4 & 4.02 & 0.92 & \\
\hline
\end{tabular}

The mean values for the facilitating conditions, learning motivation expectancy, and perceived teaching usefulness are pretty high. With two exceptions (ML1 and UT2) all item loadings are over .6, thus proving unidimensionality of the first-order factors. The Cronbach's alpha is varying from .532 to .833 , thus showing acceptable reliability of the scales.

Table 3

Scale reliability, convergent, and discriminant validity $(N=125)$

\begin{tabular}{llllllll}
\hline & Alpha & CR & AVE & FC & ML & UU & UT \\
\hline FC & .532 & 0.728 & 0.574 & 0.758 & & & \\
\hline ML & .833 & 0.843 & 0.577 & 0.365 & 0.759 & & \\
\hline UU & .763 & 0.785 & 0.650 & 0.256 & 0.506 & 0.806 & \\
\hline UT & .828 & 0.836 & 0.563 & 0.470 & 0.728 & 0.787 & 0.751 \\
\hline
\end{tabular}

Note: The bold diagonal numbers represent the square root of AVE

The convergent validity is very good since the composite reliability (CR) and average variance extracted (AVE) are over the cut-off values of 0.7 , respectively 0.5 (Fornell \& Larcker, 1981). The discriminant validity is also good, with one exception (correlation between UU and UT exceeds the square root of AVE for UT). 
Gabriel GORGHIU, Costin PRIBEANU, Vincentas LAMANAUSKAS, Violeta SLEKIENE. Usefulness of mobile teaching and learning as perceived by Romanian and Lithuanian science teachers

PROBLEMS

OF EDUCATION

IN THE $21^{\text {st }}$ CENTURY

Vol. 78 , No. 5, 2020

\section{Figure 2}

Model estimation results - Romanian sample $(N=125)$

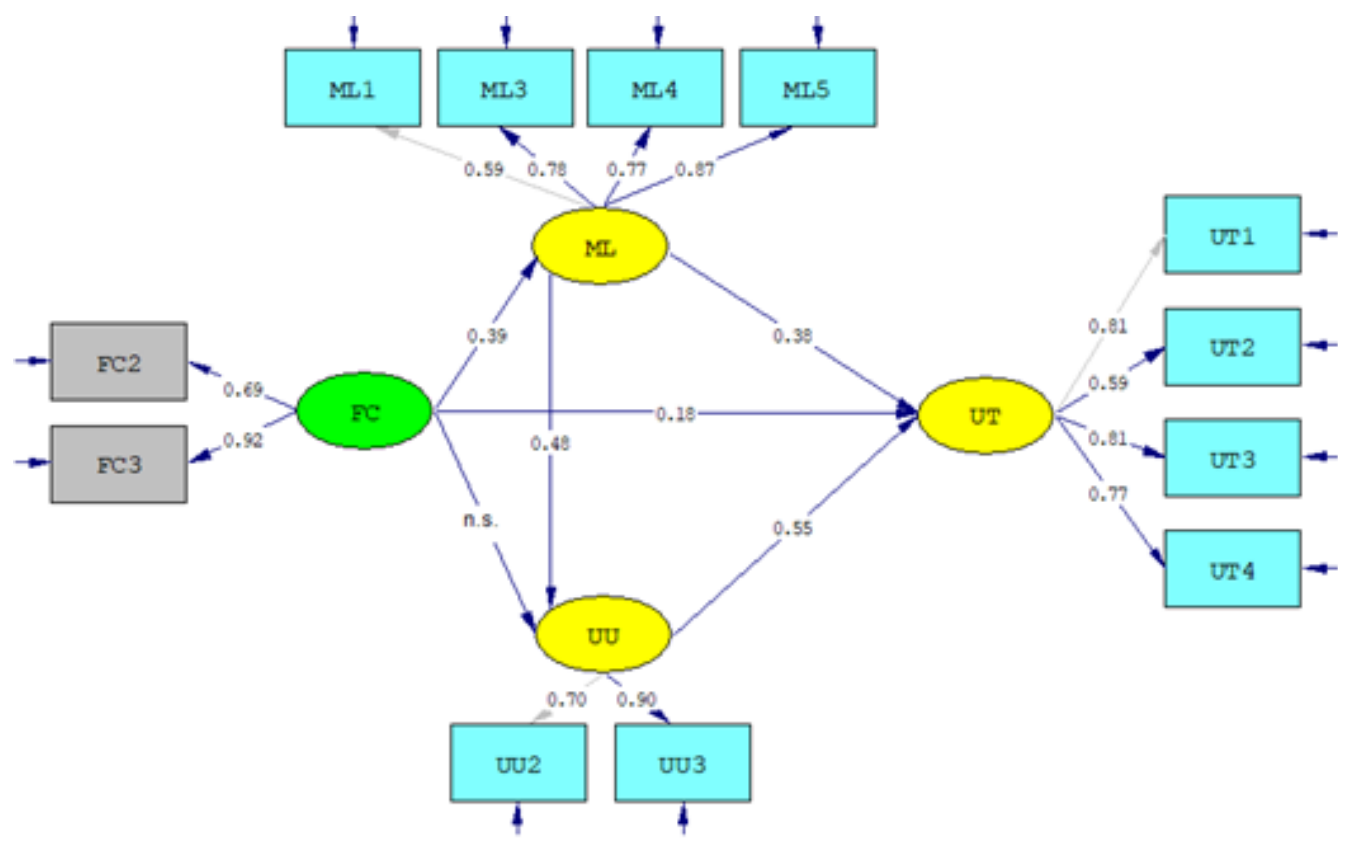

Chi-Square=84.36, df =48, P-value=0.00093, RMSEA $=0.078$

The model fit with the data is also good, as shown by the goodness of fit (GOF) indices: $\chi^{2}=84.36, d f=48, \chi^{2} / d f=1.758, \mathrm{CFI}=0.949, \mathrm{GFI}=0.904, \mathrm{RMSEA}=0.078, \mathrm{SRMR}=0.054$. The model estimation results for the Romanian sample are presented in Figure 2.

The path from FC to UU is not significant so the hypothesis $\mathrm{H}_{2}$ is not supported. $\mathrm{H} 1$ and $\mathrm{H}_{3}$ are supported since the paths from FC to ML and UT are significant ( $p=.001$, respectively $p=.016$ )

The learning motivation expectancy has a significant positive influence on both the better understanding expectancy $(p=.0001)$ and teaching usefulness (.0001) thus showing that $\mathrm{H}_{4}$ and $\mathrm{H}_{5}$ are supported. The better understanding expectancy has a significant positive influence on the teaching usefulness $(p=.0001)$ thus providing evidence that $\mathrm{H}_{6}$ is supported.

The model explains $14.8 \%$ variance in the expectancy for learning motivation (ML), $26 \%$ variance in the expectancy for better understanding (UU), and $79.4 \%$ variance in the usefulness for teaching. 
Gabriel GORGHIU, Costin PRIBEANU, Vincentas LAMANAUSKAS, Violeta SLEKIENE. Usefulness of mobile teaching and learning as perceived by Romanian and Lithuanian science teachers

The descriptive statistics and item loadings are presented in Table 4 .

Table 4

Descriptive and item loadings ( $N=120)$

\begin{tabular}{|c|c|c|c|c|c|c|c|}
\hline Factor & Item & Mean & $S D$ & Loading & Alpha & CR & AVE \\
\hline \multirow{2}{*}{ FC } & $\mathrm{FC} 1$ & 3.80 & 0.74 & .66 & \multirow[t]{2}{*}{.591} & \multirow[t]{2}{*}{0.699} & \multirow[t]{2}{*}{0.539} \\
\hline & FC2 & 3.89 & 0.71 & .80 & & & \\
\hline \multirow[t]{4}{*}{$M L$} & ML1 & 4.13 & 0.65 & .70 & \multirow[t]{4}{*}{.835} & \multirow[t]{4}{*}{0.851} & \multirow[t]{4}{*}{0.591} \\
\hline & ML3 & 4.13 & 0.69 & .81 & & & \\
\hline & ML4 & 3.68 & 0.72 & .68 & & & \\
\hline & ML5 & 4.16 & 0.61 & .87 & & & \\
\hline \multirow[t]{2}{*}{ UU } & UU2 & 3.58 & 0.78 & .67 & \multirow[t]{2}{*}{.674} & \multirow[t]{2}{*}{0.677} & \multirow[t]{2}{*}{0.513} \\
\hline & UU3 & 3.84 & 0.67 & .76 & & & \\
\hline \multirow[t]{4}{*}{ UT } & UT1 & 4.24 & 0.62 & .77 & \multirow[t]{4}{*}{.783} & \multirow[t]{4}{*}{0.784} & \multirow[t]{4}{*}{0.479} \\
\hline & UT2 & 4.15 & 0.60 & .56 & & & \\
\hline & UT3 & 3.96 & 0.56 & .67 & & & \\
\hline & UT4 & 3.68 & 0.69 & .74 & & & \\
\hline
\end{tabular}

All item loadings are over 0.6 , thus proving the unidimensionality of the first-order factors.

Table 5

Scale reliability, convergent, and discriminant validity $(N=120)$

\begin{tabular}{llllllll}
\hline & Alpha & CR & AVE & FC & ML & UU & UT \\
\hline FC & .591 & 0.699 & 0.539 & 0.734 & & & \\
\hline ML & $.835-$ & 0.851 & 0.591 & 0.577 & 0.935 & & \\
\hline UU & .674 & 0.677 & 0.513 & 0.564 & 0.690 & 0.795 & \\
\hline UT & .783 & 0.784 & 0.479 & 0.151 & 0.816 & 0.896 & 0.880 \\
\hline
\end{tabular}

Note: The bold diagonal numbers represent the square root of AVE

The Cronbach's alpha is varying from .591 to .835 , thus showing acceptable reliability of the scales. The convergent validity is acceptable since, with one exception (UU) the composite reliability (CR) is over 0.7 , and, with one exception (UT) the average variance extracted (AVE) is over 0.5 . The discriminant validity is also acceptable, with two exceptions (correlation of UT with ML and UU). 
Gabriel GORGHIU, Costin PRIBEANU, Vincentas LAMANAUSKAS, Violeta SLEKIENE. Usefulness of mobile teaching and learning as perceived by Romanian and Lithuanian science teachers

PROBLEMS

OF EDUCATION

IN THE $21^{\text {st }}$ CENTURY

Vol. 78 , No. 5, 2020

The model fit with the data is very good: $\chi^{2}=62.86, d f=48, \chi^{2} / d f=1.309$, CFI $=0.973$, $\mathrm{GFI}=0.920, \mathrm{RMSEA}=0.051, \mathrm{SRMR}=0.051$. The model estimation results for the Lithuanian sample are presented in Figure 3.

\section{Figure 3}

Model estimation results - Lithuanian sample $(N=120)$

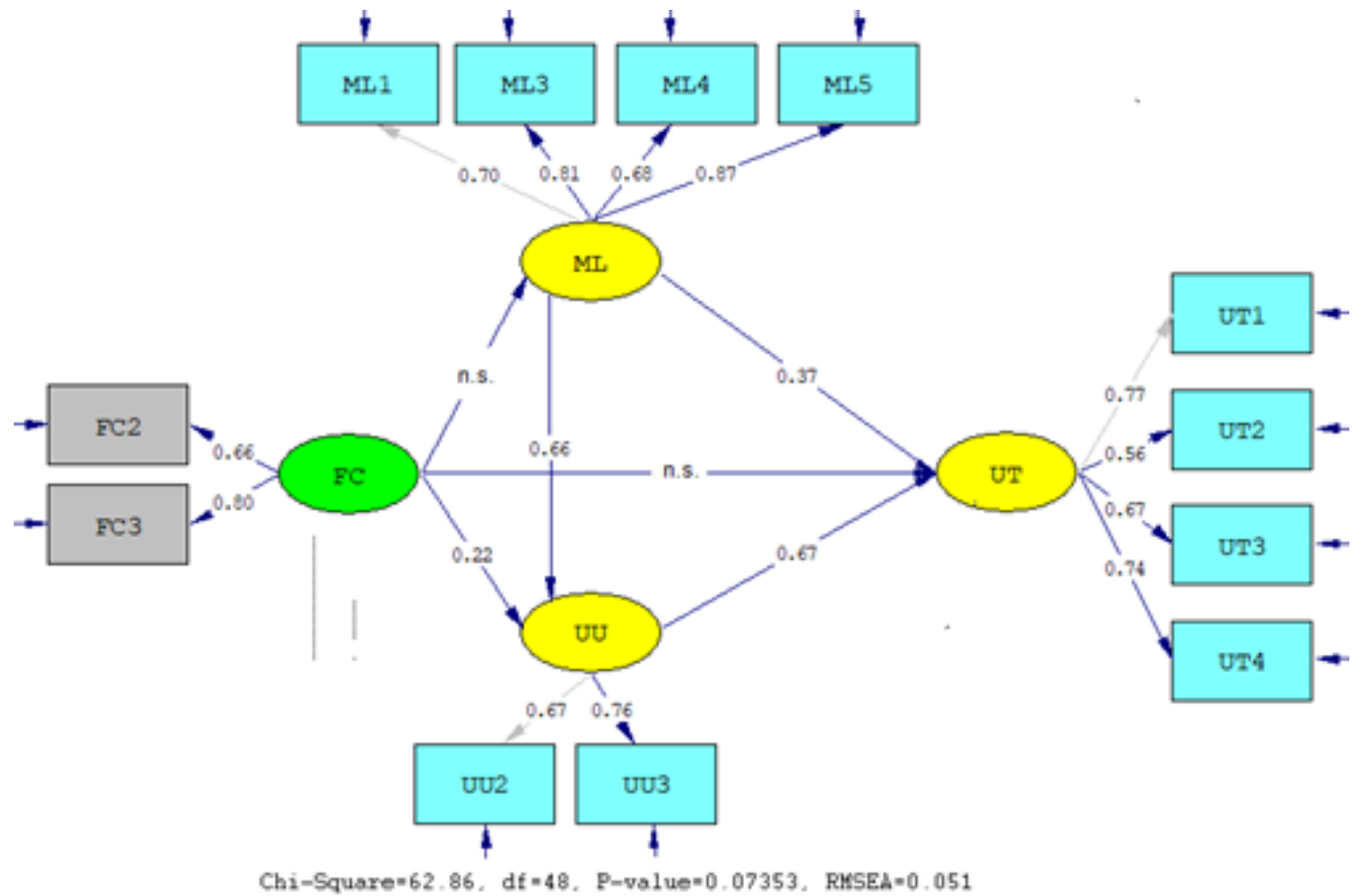

The paths from FC to ML and $\mathrm{FC}$ are not significant so the hypotheses $\mathrm{H}_{1}$ and $\mathrm{H}_{3}$ are not supported. The path from FC to UU is marginally significant $(p=.056)$ therefore the hypothesis $\mathrm{H}_{2}$ is supported.

The learning motivation expectancy has a significant positive influence on both the better understanding expectancy $(p=.0001)$ and teaching usefulness $(.016)$ thus showing that $\mathrm{H}_{4}$ and $\mathrm{H}_{5}$ are supported. In turn, a better understanding of expectancy has a significant positive influence on the teaching usefulness $(p=.001)$ thus providing evidence that $\mathrm{H}_{6}$ is supported.

The model explains $2.3 \%$ variance in the expectancy for learning motivation (ML), $52.3 \%$ variance in the expectancy for better understanding (UU), and $88.3 \%$ variance in the usefulness for teaching.

\section{Discussion}

This research contributes with an empirically validated model that explains the relationship between the facilitating conditions and the teaching and learning outcomes as regards the use of mobile technology in the teaching and learning process. Since the model has been cross-validated on a different sample, the scale is pretty reliable for a pilot study.

In both samples, the $\mathrm{H}_{4}, \mathrm{H}_{5}$, and $\mathrm{H}_{6}$ hypotheses were supported thus showing that the expectancies as regards the students' increased motivation and better understanding have positive and significant effects on the perceived teaching usefulness. The strength of path from ML to UU and the variance explained in the better understanding expectancy shows that the 
motivation to learn makes students more receptive thus helping understanding of concepts,

which confirms the findings of other studies (Brophy, 1998; Garcia-Martinez et al., 2019; Ferreira et al., 2015; Lamanauskas et al., 2019).

The model explains a lot of variance in the perceived usefulness for teaching ( $79 \%$ for the Romanian sample, respectively $88 \%$ for the Lithuanian sample). This shows awareness of teachers that in the current situation the motivation to learn and understanding concepts are key issues that could be better approached by integrating mobile technology in the educational process (Heflin et al., 2017; Lamanauskas et al., 2019).

An important factor of this empiric research is that natural science teachers from two countries took part in it. Research metanalysis carried out by Alrasheedi and Capretz (2015) showed that teachers' technological competence is not considered a very significant success factor. Researchers notice that research studies are very often focused on perceived benefits from learner perspectives (students), at the same time ignoring the other users, for example, teachers. Therefore, from the teachers' perspective, evaluation research studies remain not less important. Researchers notice that empiric research related to perceptions and usefulness on mobile technology and mobile learning is still limited (Nikolopoulou, 2020). This research at least partially fills this gap. Though MT distinguishes itself by various advantages, potential, and ability to customize individual experiences (Carvalho \& Ferreira, 2015), the teacher's role remains important. Not all teachers (especially seniors) appropriately and effectively use MT in the teaching process. The research shows, that teachers' position concerning mobile devices changes significantly according to teachers' ages (Cumaoğlu, 2015). Meanwhile, regardless of MT diversity, students prefer to learn from their teachers and rather than from a mobile device (Rodriguez, 2018). The research shows that in such cases, pedagogical and technological support is necessary for the teachers (Seifert, 2016).

Since this is a pilot study, there are some inherent limitations. The first limitation is the small number of items for two constructs. The second limitation is related to the sample size, which is at limits for structural equation modeling requirements. The third limitation is related to the non-supported hypotheses (paths from FC to UU, ML, and UT) which suggests revising the FC (facilitating conditions) construct.

\section{Conclusions}

The results of this research provide useful insights into the relations between the learning motivation expectancy, better understanding expectancy, and usefulness for teaching with mobile devices.

To find out the influence of increased students' motivation and a better understanding of the perception of the usefulness of mobile teaching, a structural model was developed and tested on two samples of science teachers (one from Romania, the other from Lithuania).

The results of the estimation of the model for the Romanian sample showed that

- the positive influence of facilitating conditions on better understanding is not significant (hypothesis $\mathrm{H}_{2}$ is not supported);

- facilitating conditions have a positive influence on the motivation to learn and on the usefulness for teaching (hypothesis $\mathrm{H}_{1}$ and $\mathrm{H}_{3}$ are supported).

The results of the estimation of the model for the Lithuanian sample showed that

- the positive influence of facilitating conditions on the motivation to learn and on the usefulness for teaching is not significant (hypothesis $\mathrm{H}_{1}$ and $\mathrm{H}_{3}$ are not supported);

- facilitating conditions have a positive influence on better understanding (hypothesis $\mathrm{H}_{2}$ is supported). 
Gabriel GORGHIU, Costin PRIBEANU, Vincentas LAMANAUSKAS, Violeta SLEKIENE. Usefulness of mobile teaching and learning as perceived by Romanian and Lithuanian science teachers

PROBLEMS

OF EDUCATION IN THE $21^{\text {st }}$ CENTURY Vol. 78, No. 5, 2020

The results of the estimation of the model for both samples (Romanian and Lithuanian) showed that

- $\quad$ the learning motivation expectancy has a significant positive influence on both the better understanding expectancy and teaching usefulness (hypothesis $\mathrm{H}_{4}$ and $\mathrm{H}_{5}$ are supported);

- the better understanding expectancy has a significant positive influence on the teaching usefulness (hypothesis $\mathrm{H}_{6}$ is supported).

Summarizing the results, it can be said that the expectancy that students will better understand lessons has a significant impact on teachers' perceptions of mobile teaching and learning.

\section{References}

Acelajado, J. M. (2011). Blended learning: A strategy for improving the mathematics achievement of students in a bridging program. Electronic Journal of Mathematics and Technology, 5(3), 342351.

Agrawal, M., \& Parvez, M. (2018). Enhancement of quality education and academic performance through mobile technology: A conceptual framework. International Journal of Advanced Educational Research, 3(2), 261-264. https://doi.org/10.22271/educationjournal.2018.v3.i2.72

Alrasheedi, M., \& Capretz, L. F. (2015). Determination of critical success factors affecting mobile learning: A meta-analysis approach. Turkish Online Journal of Educational Technology, 14(2), 41-51.

Anderson, J. C., \& Gerbing, D. W. (1988) Structural equation modeling in practice: A review and recommended two-step approach. Psychological Bulletin, 103(3), 411423. https://doi.org/10.1037/0033-2909.103.3.411

Birch, S. H., \& Ladd, G. W. (1997). The teacher-child relationship and children's early school adjustment. Journal of School Psychology, 35, 61-79.

Brophy, J. (1998). Motivating students to learn. McGraw Hill.

Carvalho, L., \& Ferreira, M. J. (2015). Mobile devices in school in the teaching/learning process - the roadmap. In Proceedings of EDULEARN15 Conference 6th-8th July 2015 (pp. 4623-4634). Barcelona, Spain. http://repositorio.uportu.pt/bitstream/11328/1432/1/1154.pdf

Chaka, J. G., \& Govender, I. (2020). Implementation of mobile learning using a social network platform: Facebook. Problems of Education in the 21st Century, 78(1), 2447. https://dx.doi.org/10.33225/pec/20.78.24

Ciampa, K. (2013). Learning in a mobile age: An investigation of student motivation. Journal of Computer Assisted Learning, 30(1), 82-96. https://doi.org/10.1111/jcal.12036

Cumaoğlu, G. K. (2015). How mobile devices affect students according to teachers' beliefs. Journal of International Education Research, 11(4), 217-229.

Dichev, C., \& Dicheva, D. (2017). Gamifying education: What is known, what is believed, and what remains uncertain: A critical review. International Journal of Educational Technology in Higher Education, 14(1), 9-45.

Ferreira, M. J., Moreira, F., Pereira, C. S., \& Durão, N. (2015). The role of mobile technologies in the teaching/learning process improvement in Portugal. In Proceedings of ICERI 2015 Conference (16th-18th November 2015, Seville, Spain) (pp. 4600-4610). International Academy of Technology, Education, and Development (IATED).

Fornell, C., \& Larcker, D. F. (1981). Evaluating structural equation models with unobservable variables and measurement error. Journal of Marketing Research, 18(1), 39-50. https://psycnet.apa.org/doi/10.2307/3151312

Fua, Q.-K., \& Hwangb, G.-J. (2018). Trends in mobile technology-supported collaborative learning: A systematic review of journal publications from 2007 to 2016. Computers \& Education, 119, 129143. https://doi.org/10.1016/j.compedu.2018.01.004

García-Martínez, I., Fernández-Batanero, J. M., Sanchiz, D. C., \& Rosa, A. D. (2019). Using mobile devices for improving learning outcomes and teachers' professionalization. Sustainability, 11, 6917. https://doi.org/10.3390/su11246917 
Gray, D. E., Ryan, M., \& Coulon, A. (2004). The training of teachers and trainers: Innovative practices, skills, and competencies in the use of e-learning. European Journal of Open, Distance, and IN THE $21^{\text {st }}$ CENTURY E-learning. https://www.eurodl.org/index.php?p=archives\&year=2004\&halfyear=2\&article=159

Hair, J. F., Black, W. C., Babin, B. J., Anderson, R. E., \& Tatham, R. L. (2006). Multivariate data analysis (6th Ed.). Prentice-Hall.

Harrison, R., Flood, D. \& Duce, D. (2013). Usability of mobile applications: Literature review and rationale for a new usability model. Journal of Interaction Science, 1, 1-16.

Heflin, H., Shewmaker, J., \& Nguyen, J. (2017). Impact of mobile technology on student attitudes, engagement, and learning. Computers \& Education, 107, 9199. https://doi.org/10.1016/j.compedu.2017.01.006

Hung, J. - L., \& Zhang, K. (2012). Examining mobile learning trends 2003-2008: A categorical metatrend analysis using text mining techniques. Journal of Computer Higher Education, 24(1), 1-17. https://doi.org/10.1007/s12528-011-9044-9

Ison, A., Hayes, A., Robinson, S., \& Jamieson, J. (2004). Txt Me: Supporting disengaged youth using mobile technologies. New practices in flexible learning. Project report for supporting flexible learning opportunities: Australian National Training Authority.

Kim, D-J., Kim, D-S., \& Choi, S-H. (2016). How does the use of mobile devices affect teachers' perceptions on mobile learning? In International Conferences ITS, ICEduTech, and STE 2016. https://files.eric.ed.gov/fulltext/ED571559.pdf

Klopfer, E., Sheldon, J., Perry, J., \& Chen, V. H.-H. (2012). Ubiquitous games for learning (UbiqGames): Weatherlings, a worked example. Journal of Computer Assisted Learning, 28, 465-476.

Lamanauskas, V., Pribeanu, C., Šlekienè, V., \& Gorghiu, G. (2020). Exploring the usefulness of mobile technology in the teaching/learning process: A multidimensional approach. In: DIVAI 2020 - The $13^{\text {th }}$ international scientific conference on Distance Learning in Applied Informatics (September 21-23, 2020, Šturovo) (pp. 149-160). Wolters Kluwer.

Lamanauskas, V., Slekiene, V., Gorghiu, G., \& Pribeanu, C. (2019). Better learning and increased motivation to learn with mobile technology (devices): A preliminary study. Gamtamokslinis ugdymas / Natural Science Education, 16(2), 80-88. http://oaji.net/articles/2020/514-1580197120. pdf

Lan, Y. J., Sung, Y. T., \& Chang, K. E. (2007). A mobile-device-supported peer-assisted learning system for collaborative early EFL reading. Language Learning \& Technology, 11, 130-151.

Lin, H.-H., Wang, Y.-S., \& Li, C.-R. (2016). Assessing mobile learning systems' success. International Journal of Information and Education Technology, 6(7), 576-579. http://10.7763/IJIET.2016.V6.754

Mels, G. (2006). LISREL for Windows: Getting started guide. Scientific Software International.

Murayama, K., Pekrun, R., Lichtenfeld, S., \& Vom Hofe, R. (2013). Predicting long-term growth in students' mathematics achievement: the unique contributions of motivation and cognitive strategies. Child Development, 84(4), 1475-1490.

Navaridas, F., Santiago, R., \& Tourón, J. (2013). Opinions from teachers in the Fresno area of Central California regarding the influence of mobile technology on their students' learning. RELIEVE: e-Journal of Educational Research, Assessment, and Evaluation, 19(2), 1-18.

Nganji, J. T. (2018). Towards learner-constructed e-learning environments for effective personal learning experiences. Behaviour \& Information Technology, 37(7), 647-657.

Nikolopoulou, K. (2020). Secondary education teachers' perceptions of mobile phone and tablet use in classrooms: Benefits, constraints, and concerns. Journal of Computers in Education, 7, 257-275. https://doi.org/10.1007/s40692-020-00156-7

Ott, T., Magnusson, A. G., Weilenmann, A., \& Segerstad, Y. H. (2018). "It must not disturb, it's as simple as that": Students' voices on mobile phones in the infrastructure for learning in Swedish upper secondary school. Education and Information Technologies, 23, 517-536.

Pintrich, P. R. (2003). A motivational science perspective on the role of student motivation in learning and teaching contexts. Journal of Educational Psychology, 95(4), 667-686.

Pribeanu, C., Gorghiu, G., Lamanauskas, V., \& Slekiene, V. (2020). Use of mobile technology in the teaching/learning process: Opportunities and barriers. In. eLearning sustainment for never-ending learning (The 16th International Scientific Conference eLearning and Software for Education) (Bucharest, April 23-24, 2020) (Vol. 1, pp. 376-383). Carol I National Defence University Publishing House. https://doi.org/10.12753/2066-026X-20-049

Rideout, V. J., Foehr, U. G., \& Roberts, D.F. (2010). Generation M2: Media in the lives of 8 to 18 years old. Henry Kaiser Family Foundation. 
Gabriel GORGHIU, Costin PRIBEANU, Vincentas LAMANAUSKAS, Violeta SLEKIENE. Usefulness of mobile teaching and learning as perceived by Romanian and Lithuanian science teachers

PROBLEMS

OF EDUCATION

IN THE $21^{\text {st }}$ CENTURY

Vol. 78, No. 5, 2020

732

Rodriguez, J. (2018). Effects of mobile technology on students in the classroom. Capstone projects and master's theses. 264. California State University. https://digitalcommons.csumb.edu/caps_thes_ all/264

Roschelle, J., Rafanan, K., Bhanot, R., Estrella, G., Penuel, B., Nussbaum, M., \& Claro, S. (2010). Scaffolding group explanation and feedback with handheld technology: Impact on students' mathematics learning. Educational Technology Research and Development, 58(4), 399-419.

Saritepeci, M., \& Cakir, H. (2015). The effect of blended learning environments on student motivation and student engagement: A study on social studies course. Education and Science, 40(177), 203216.

Schermelleh-Engel, K., Moosbrugger, H., \& Müller, H. (2003). Evaluating the fit of structural equation models: Tests of significance and descriptive goodness-of-fit measures. Methods of Psychological Research Online, 8(2), 23-74.

Seifert, T. (2016). Patterns of mobile technology use in teaching: The teacher's perspective. i-manager's Journal of Educational Technology, 13(3), 1-17. https://doi.org/10.26634/jet.13.3.8316

Sivakumar, R. (2014). 3G - mobile technology in education. Cognitive Discourses International Multidisciplinary Journal, 2(1), 49-53.

Sung, E., \& Mayer, R. E. (2013). Online multimedia learning with mobile devices and desktop computers: An experimental test of Clark's methods-not-media hypothesis. Computers in Human Behavior, 29(3), 639-647.

Thomas, K, \& Muñoz, M. A. (2016). Hold the phone! High school students' perceptions of mobile phone integration in the classroom. American Secondary Education, 44(3), 19-37.

Walker, R. (2013). "I don't think I would be where I am right now": Pupil perspectives on using mobile devices for learning. Research in Learning Technology, 21, 1-12.

Warschauer, M. (2007). A teacher's place in the digital divide. Yearbook of the National Society for the Study of Education, 106, 147-166.

Received: May 25, 2020

Accepted: September 15, 2020 
Gabriel GORGHIU, Costin PRIBEANU, Vincentas LAMANAUSKAS, Violeta SLEKIENE. Usefulness of mobile teaching and learning as perceived by Romanian and Lithuanian science teachers

PROBLEMS

OF EDUCATION

IN THE $21^{\text {st }}$ CENTURY

Vol. 78, No. 5, 2020

733

Cite as: Gorghiu, G., Pribeanu, C., Lamanauskas, V., \& Šlekienė, V. (2020). Usefulness of mobile teaching and learning as perceived by Romanian and Lithuanian science teachers. Problems of Education in the $21^{\text {st }}$ Century, 78(5), 719733. https://doi.org/10.33225/pec/20.78.719

\begin{tabular}{|c|c|}
\hline Gabriel Gorghiu & $\begin{array}{l}\text { PhD, Professor, Teacher Training Department, Valahia University Targoviste, } \\
35 \text { Lt. Stancu lon Street, } 130105 \text { Targoviste, Romania. } \\
\text { E-mail: ggorghiu@gmail.com } \\
\text { Website: https://www.researchgate.net/profile/Gabriel_Gorghiu } \\
\text { ORCID: https://orcid.org/0000-0002-4026-345X }\end{array}$ \\
\hline $\begin{array}{l}\text { Costin Pribeanu } \\
\text { (Corresponding author) }\end{array}$ & $\begin{array}{l}\text { PhD, Senior Researcher, Academy of Romanian Scientists, Splaiul } \\
\text { Independentei no. 54, sector 5, 050094 Bucharest, Romania. } \\
\text { E-mail: costin.pribeanu@gmail.com } \\
\text { Website: https://www.researchgate.net/profile/Costin_Pribeanu } \\
\text { ORCID: https://orcid.org/0000-0001-8182-5909 }\end{array}$ \\
\hline Vincentas Lamanauskas & $\begin{array}{l}\text { PhD, Professor, Senior Researcher, Institute of Education, Šiauliai University, } \\
\text { P. Visinskio Street 25-119, LT-76351 Siauliai, Lithuania. } \\
\text { E-mail: vincentas.lamanauskas@su.It } \\
\text { Website: http://www.lamanauskas.puslapiai.lt/; } \\
\text { https://www.researchgate.net/profile/Vincentas_Lamanauskas } \\
\text { ORCID ID: http://orcid.org/0000-0002-4130-7899 }\end{array}$ \\
\hline Violeta Šlekiené & $\begin{array}{l}\text { PhD, Associate Professor, Institute of Education, Šiauliai University, 25-125 } \\
\text { P. Višinskio Street, Šiauliai, Lithuania. } \\
\text { E-mail: violeta.slekiene@su.It } \\
\text { Website: https://www.researchgate.net/profile/Violeta_Slekiene }\end{array}$ \\
\hline
\end{tabular}

